\title{
Distribution and recurrence of phytoplankton blooms around South Georgia, Southern Ocean
}

\author{
I. Borrione and R. Schlitzer \\ Alfred Wegener Institute for Polar and Marine Research, Columbusstrasse, 7568 Bremerhaven, Germany \\ Correspondence to: I. Borrione (ines.borrione@awi.de)
}

Received: 17 July 2012 - Published in Biogeosciences Discuss.: 2 August 2012

Revised: 12 December 2012 - Accepted: 14 December 2012 - Published: 14 January 2013

\begin{abstract}
South Georgia phytoplankton blooms are amongst the largest of the Southern Ocean and are associated with a rich ecosystem and strong atmospheric carbon drawdown. Both aspects depend on the intensity of blooms, but also on their regularity. Here we use data from $12 \mathrm{yr}$ of SeaWiFS (Sea-viewing Wide Field-of-view Sensor) ocean colour imagery and calculate the frequency of bloom occurrence (FBO) to re-examine spatial and temporal bloom distributions. We find that upstream of the island and outside the borders of the Georgia Basin, blooms occurred in less than 4 out of the $12 \mathrm{yr}(\mathrm{FBO}<4)$. In contrast, FBO was mostly greater than 8 downstream of the island, i.e., to the north and northwest, and in places equal to 12 , indicating that blooms occurred every year. The typical bloom area, defined as the region where blooms occurred in at least 8 out of the $12 \mathrm{yr}$, covers the entire Georgia Basin and the northern shelf of the island. The time series of surface chlorophyll $a(\mathrm{Chl} a)$ concentrations averaged over the typical bloom area shows that phytoplankton blooms occurred in every year between September 1997 and September 2010, and that Chl $a$ values followed a clear seasonal cycle, with concentration peaks around December followed in many years by a second peak during late austral summer or early autumn, suggesting a bimodal bloom pattern. The bloom regularity we describe here is in contrast with results of Park et al. (2010) who used a significantly different study area including regions that almost never exhibit bloom conditions.
\end{abstract}

\section{Introduction}

Phytoplankton blooms play a key role in pelagic and benthic food webs, on the transfer of organic matter to the sea floor as well as on ocean biogeochemistry (Falkowski et al., 1998). In the presence of sufficient nutrient supply and light levels, phytoplankton can grow and accumulate to bloom levels where loss rates due to mortality (i.e., grazing) and sinking are exceeded. Across most of the Southern Ocean, despite the high macro-nutrient content of surface waters transported by the easterly flowing Antarctic Circumpolar Current (ACC), chlorophyll $a$ (Chl $a$ ) concentrations generally remain low and do not exceed $0.5 \mathrm{mg} \mathrm{m}^{-3}$ (Comiso et al., 1993; Moore and Abbott, 2000). According to the iron hypothesis (Martin et al., 1990), these high-nutrient, low-chlorophyll (HNLC) conditions are due to iron limitation. In fact, when iron-stress was reduced by an exogenous source of iron, as for example during artificial iron fertilization studies (Boyd et al., 2007), phytoplankton blooms were observed. In natural conditions, regular blooms develop close to coastal regions and downstream of islands, where land masses constitute reliable sources of iron; examples are the western Antarctic Peninsula (e.g., Smith et al., 2008) or the subantarctic Kerguelen and Crozet Islands (Blain et al., 2008; Pollard et al., 2009; Planquette et al., 2007).

In the southwestern Atlantic sector of the Southern Ocean (Fig. 1), strict HNLC conditions are mostly found in the southern Drake Passage region, especially to the west of the Shackleton Transverse Ridge (STR in Fig. 1), where the absence of iron sources west of Drake Passage are believed to limit phytoplankton growth (Dulaiova et al., 2009; Hopkinson et al., 2007). East of the Drake Passage, phytoplankton blooms occur in response to diverse iron fertilization processes, including shelf-sediment interactions, i.e., along the shelf and continental regions of the Antarctic Peninsula or over the southern Patagonian shelf (Ardelan et al., 2010; Hewes et al., 2008; Lutz et al., 2010), atmospheric 


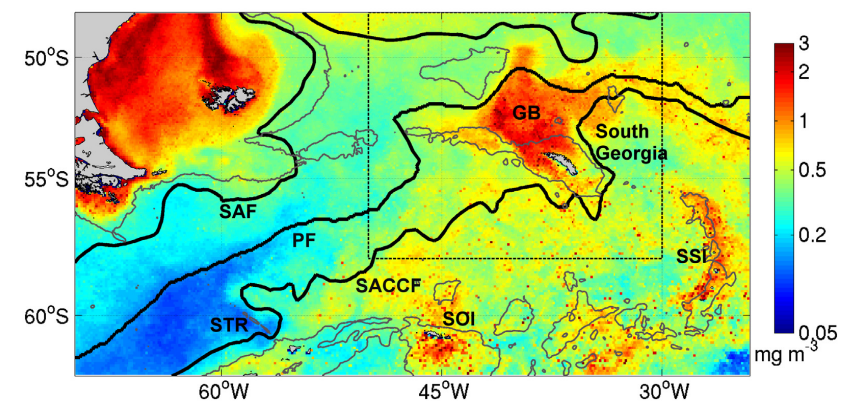

Fig. 1. Chlorophyll $a$ climatology derived from SeaWiFS austral summer (December-February, from 1997-2010) in the southwestern sector of the Atlantic Southern Ocean. Bold lines indicate the Subantarctic Front (SAF, Orsi et al., 1995), the Polar Front (PF, Moore et al., 1999) and the Southern ACC Front (SACCF, Thorpe et al., 2002). Bathymetric contours for the $2000 \mathrm{~m}$ are indicated with thin lines. The position of the Shackleton Transverse Ridge (STR), that of the South Orkney Islands (SOI), the Georgia Basin (GB) and the South Sandwich Islands (SSI) are also indicated.

dust depositions downwind of South America whether directly or following sea-ice melting (Lannuzel et al., 2007; Gassó and Stein, 2007; Smith et al., 2008), mesoscale features such eddies (Kahru et al., 2007) or iceberg melt (Lin et al., 2011). Whereas phytoplankton blooms in the open ocean waters of the Scotia Sea are short-lived and often unpredictable (Whitehouse et al., 2012), east of South America (north of the Subantarctic Front) and downstream of islands they are recorded frequently. Among all island systems of the Scotia Sea (i.e., South Orkney or the South Sandwich Islands, indicated as SOI and SSI in Fig. 1), phytoplankton blooms of South Georgia are the largest and most intense, with Chl $a$ concentrations often exceeding $10 \mathrm{mg} \mathrm{m}^{-3}$ (e.g., Korb et al., 2004).

The island of South Georgia, located at the northeastern limit of the Scotia Sea, generates the largest meander in the eastward flowing ACC. As seen in Fig. 1, just before approaching South Georgia, the Polar Front (PF) veers north, and then resumes its eastward flow north of the island (Moore et al., 1999); to the south of the island, the Southern ACC Front (SACCF), which approaches South Georgia from the southwest, kinks westwards towards the Georgia Basin before resuming its eastwards course (Orsi et al., 1995; Thorpe et al., 2002; Boehme et al., 2008). In response to this particular hydrography of the region, South Georgia phytoplankton blooms develop to the northwest of the island over the deep waters of the Georgia Basin (3500-4000 m, see Fig. 2 for a map of bathymetry around South Georgia).

The highly productive environment of South Georgia is known to sustain a rich ecosystem, characterized by large stocks of krill, numerous colonies of marine and land-based predators (Atkinson et al., 2001), as well as a shelf region reported to have the highest recorded biodiversity in the Southern Ocean (Hogg et al., 2011). Consequently, much attention

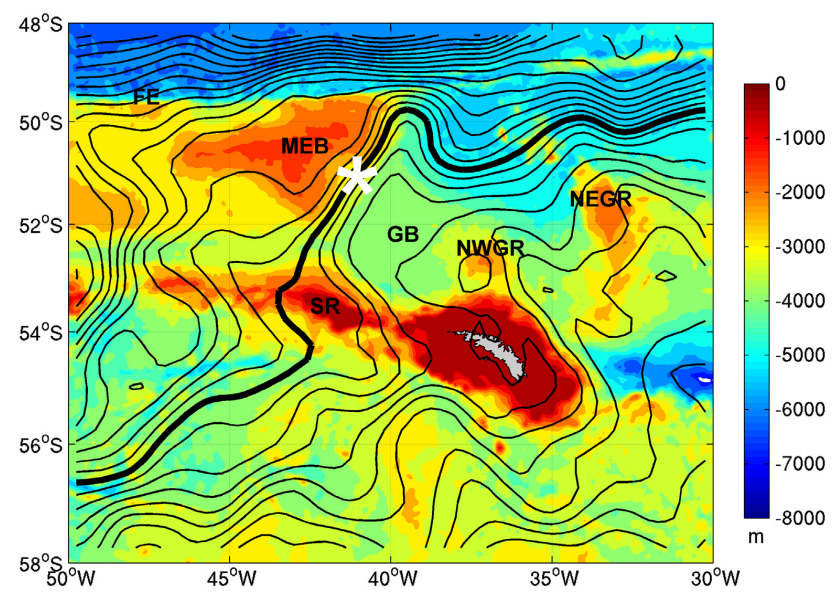

Fig. 2. Bathymetry (in colour) and climatological circulation (black lines) in the South Georgia region. Black lines correspond to Aviso dynamic topography isopleths for the summer climatology (December-February, from 1997-2010). Isopleths are equally spaced every 5 dyn $\mathrm{cm}$, and dynamic topography values decrease from north to south; for reference, the -71 dyn $\mathrm{cm}$ contour line used by Venables et al. (2012) to locate the southern extent of the Polar Front is shown in bold. FE: Falkland Escarpment, MEB: Maurice Ewing Bank, GB: Georgia Basin, SR: Shag Rocks, NWGR: North West Georgia Rise and NEGR: North East Georgia Rise. The position of the MEB-GB margin, referred to in the text, is indicated with a white star.

has been dedicated to the understanding of primary productivity regimes associated to South Georgia, by means of shipboard measurements (e.g., Whitehouse et al., 2008a; Korb and Whitehouse, 2004), as well as from satellite imagery (Korb et al., 2004, 2012; Park et al., 2010). These studies mostly focussed on the region located south of $50^{\circ} \mathrm{S}$, in particular on the southern portion of the Georgia Basin and the island's shelf. Results have indicated phytoplankton growing seasons ranging between 3 and 6 months, as well as significant spatial and temporal variability in surface $\mathrm{Chl} a$ concentrations. In particular, a recent multi-year study indicated that around South Georgia phytoplankton blooms showed low predictability and no regular seasonality (Park et al., 2010). Considering that the shelf of South Georgia is likely providing a reliable supply of shelf-derived iron, similar to the other major subantarctic islands of the Southern Ocean (i.e., those of the Crozet and Kerguelen plateaus; Blain et al., 2008; Pollard et al., 2009; Chever et al., 2010) one would expect the presence of regular seasonal blooms; hence, the results of Park et al. (2010) are rather unexpected.

In this study we utilize satellite ocean colour imagery to re-examine the spatial and temporal patterns of primary productivity associated to South Georgia. Following Korb et al. (2008) we define phytoplankton blooms as Chl $a$ values equal or greater than $0.75 \mathrm{mg} \mathrm{m}^{-3}$. Our area of study, the South Georgia region (rectangle in Fig. 1), was chosen in order to include the entire main bloom area revealed by the 
summer climatology and lies between $\left(50^{\circ} \mathrm{W}-30^{\circ} \mathrm{W}\right)$ and $\left(48^{\circ} \mathrm{S}-58^{\circ} \mathrm{S}\right)$.

\section{Data and methods}

\subsection{Ocean colour measurements}

The 13 year-long time series of Sea-viewing Wide Field-ofview Sensor (SeaWiFS) data (McClain et al., 1998) was used for this study. Satellite imagery in fact, remains the preferential tool for a quasi-synoptic view of a region as large as that surrounding South Georgia.

Freely available Standard Mapped Images - Level 3 (SMIL3) products, for the years between 1997 and 2010, combined to form monthly and eight-day Chl $a$ averages, processed by the Goddard Space Flight Center and projected on a regular spatial grid of $9 \mathrm{~km}$, were retrieved from the Distributed Active Archive Center (http://oceancolor.gsfc.nasa. gov/). In our analysis we focus on the austral summer (December to February) as this is the period when Chl $a$ biomass reaches its peak concentrations and coincides with the season when most oceanographic cruises are conducted and cloud cover is reduced. No SeaWiFS data are available for the months of January and February 2008, therefore we excluded the 2007/2008 summer season from the calculation of frequency of bloom occurrences (see below).

Several efforts have been made to validate SeaWiFS measurements with in situ data collected in Antarctic waters. Although results may differ between regions of interest, it is a general agreement that the SeaWiFS global chlorophyll algorithm performs adequately when compared to direct measurements of Chl $a$ (Arrigo et al., 2008; Korb et al., 2004; Holm-Hansen et al., 2004) albeit concentrations above $\sim 0.5 \mathrm{mg} \mathrm{m}^{-3}$ are underestimated (Garcia et al., 2005; Szeto et al., 2011).

\subsection{Pixel count algorithm and frequency of bloom occurrences}

The focus of this study is to investigate the spatial and temporal dynamics of $\mathrm{Chl} a$ concentrations that pertain to phytoplankton bloom conditions. Southern Ocean blooms were distinguished by Comiso et al. (1993) as having Chl $a$ values $>1 \mathrm{mg} \mathrm{m}^{-3}$. However, because of the tendency of SeaWiFS to underestimate mid- to higher Chl $a$, we chose $0.75 \mathrm{mg} \mathrm{m}^{-3}$ as a threshold value to define phytoplankton blooms, which has been also used by Korb et al. (2008) and is very close to the $0.8 \mathrm{mg} \mathrm{m}^{-3}$ value adopted by Fitch and Moore (2007). Consequently, only Chl $a$ concentrations higher than $0.75 \mathrm{mg} \mathrm{m}^{-3}$ were accounted for and grouped in a single bloom category, independent from the bloom magnitude.

For every SeaWiFS data pixel in the South Georgia region (domain indicated in Fig. 1) we calculate the DecemberFebruary austral summer average for each of the $12 \mathrm{yr}$ be- tween 1997 and 2010; missing values (i.e., due to cloud cover) were excluded in the calculations. In each of the 12 December-February austral summer averages, nearly all pixels from the main South Georgia bloom region contain Chl $a$ concentration data. Then we calculate for every pixel the number of years (i.e., the number of austral summer averages) during which $\mathrm{Chl} a$ concentrations exceeded the bloom threshold value $0.75 \mathrm{mg} \mathrm{m}^{-3}$.

Results are displayed as frequency of bloom occurrence (FBO) plots, where the colour scale indicates the number of summer seasons when $\mathrm{Chl} a$ concentrations corresponded to bloom conditions. For each pixel in the frequency plot $\left(\sim 60 \mathrm{~km}^{2}\right)$, the obtained FBO give an indication of the recurrence, and hence the predictability level of phytoplankton blooms. Phytoplankton blooms can be considered very recurrent (hence very predictable) in regions where FBO are closest to 12 , which is the total number of austral summer seasons included in the analysis. Intermediate FBO $(\sim 6)$ indicate that $\mathrm{Chl} a$ concentrations fell recurrently both above and below the threshold (i.e., pronounced variability) in the 12 -year period while reduced FBO $(\mathrm{FBO}<4)$ indicate less frequent or rare bloom events.

To assess the sensitivity of the results to the chosen threshold, we repeated the calculations with slightly different values (i.e., $0.7 \mathrm{mg} \mathrm{m}^{-3}$ or $0.8 \mathrm{mg} \mathrm{m}^{-3}$ ), but found nearly identical patterns in all cases. Further, we checked that the results obtained from the FBO calculated from seasonal averages (i.e., trimesters) is comparable to the FBO calculated by considering each summer month independently (i.e., not combined to form seasonal averages).

\subsection{Surface water circulation}

Surface circulation patterns in the South Georgia region were obtained from Aviso satellite altimetry (http://www. aviso.oceanobs.com/duacs/). Weekly, delayed-time, mapped, absolute dynamic topography data, re-sampled on a regular $0.25^{\circ}$ grid, were extracted for the months of December through February and for the period between 1997 and 2010. The Aviso altimeter product is based on multiple altimeter missions (Jason-1\&2, $T / P$, Envisat, GFO, ERS-1\&2 and Geosat) and provides a consistent and homogeneous dataset. The altimeter data were averaged to form an austral summer climatology for the 1997 to 2010 period (Fig. 2). In addition, averages for individual months were used for instantaneous comparisons with monthly ocean colour composites (Fig. 4).

Surface dynamic topography contours represent geostrophic streamlines, and indicate pathways and strength of surface circulation; the former are parallel to isopleths, while the latter are stronger when isopleths run closer.

\subsection{Macronutrients}

In order to characterize the seasonal cycle of macronutrient concentrations in the South Georgia region, we retrieved 
surface $(0-50 \mathrm{~m})$ water concentrations of nitrate, phosphate and silicate from the World Ocean Database 2009 (WOD09, Boyer et al., 2009). Data from WOD09 are distributed by the NOAA National Oceanographic Data Center (http://www. nodc.noaa.gov/OC5/WOD09/pr_wod09.html).

\subsection{Sea surface temperature, photosynthetically active radiation and wind speed}

SMI-L3 eight-day Terra-MODIS (Moderate Resolution Imaging Spectroradiometer) averages of sea surface temperatures (SST), processed by the Goddard Space Flight Center and projected on a regular spatial grid of $9 \mathrm{~km}$, were retrieved for the South Georgia region and for the years between 1997 and 2010, from the Distributed Active Archive Center (http://oceancolor.gsfc.nasa.gov/). From the same website, time-period and region we also retrieved SMI-L3 eightday averages of SeaWiFS photosynthetically active radiation (PAR).

Daily QuikSCAT (Quick Scatterometer) Level-4 windspeed measurements available between 1999 and 2009 were retrieved for the South Georgia region from the Center for Satellite Exploitation and Research (CERSAT, http://www. ifremer.fr/opendap/cerdap1/cersat/wind/14/quikscat/daily/).

To evaluate how SST, PAR and wind speed influence the temporal evolution of Chl $a$ concentrations in the South Georgia typical bloom area (see below) environmental measurements over the same area were averaged for the period 27 October-02 April of each year and for a 15-day period prior to each year's bloom onset-date (i.e., first week in which Chl $a$ were $\geq 0.75 \mathrm{mg} \mathrm{m}^{-3}$, see Table 1 and 2). From the 15day averages we subtracted the climatological values over the same 15-day period to remove the effect of the seasonal cycle: towards the summer, SST and PAR are likely to increase, while wind speed is likely to decrease. Hence, in the correlations with dates of bloom onset we used 15-day SST, PAR and wind-speed anomalies. All values used in the correlations (i.e., growth-season averages, 15-day anomalies and bloom onset-dates) as well as the obtained correlation coefficients are reported in Table 2 and discussed in Sect. 4.

\section{Results}

\subsection{Austral summer climatology}

The Chl $a$ climatological average constructed by averaging austral summer data (December to February) over the entire study period between 1997 and 2010 is depicted in Fig. 3. Chl $a$ values greater than $0.75 \mathrm{mg} \mathrm{m}^{-3}$ are present over the Georgia Basin and in the area west of the North East Georgia Rise, along the northern and southern shelf of the island as well as in the area surrounding Shag Rocks. Chl $a$ concentrations greater than $3 \mathrm{mg} \mathrm{m}^{-3}$ (shades of dark red) are indicated mostly in the southwestern portion of the basin including the northwestern shelf of the island. Overall, aver-

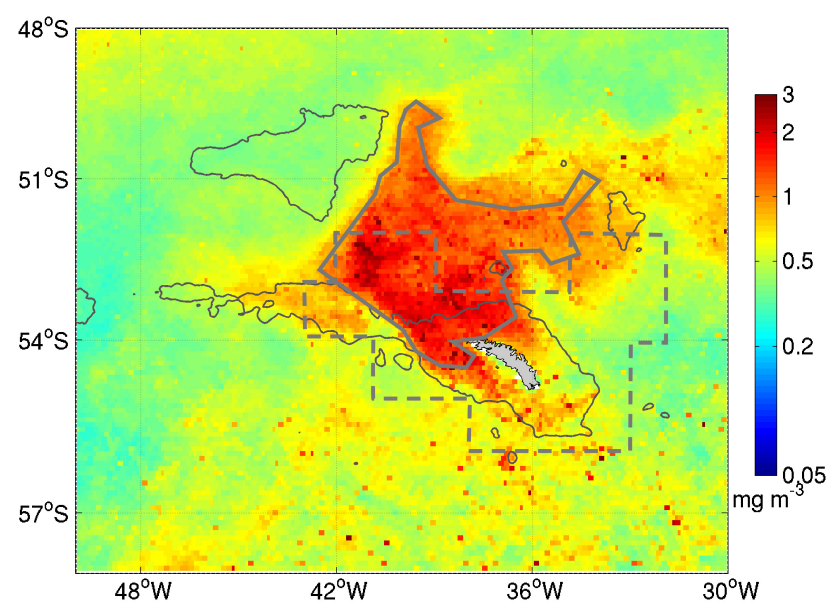

Fig. 3. Surface Chl $a$ climatology around South Georgia (detail from Fig. 1). The bold grey line marks the typical bloom area (see Sect. 3.3), and the dashed grey line marks the Georgia area utilized by Park et al. (2010). The $2000 \mathrm{~m}$ bathymetry contour is indicated with thin lines.

aged Chl $a$ values decrease in a northeasterly direction and reach values close to $0.75 \mathrm{mg} \mathrm{m}^{-3}$ in the area adjacent to the North East Georgia Rise.

\subsection{Spatial and temporal variability}

In Fig. 4 we show SeaWiFS Chl $a$ data (colours) as well as satellite altimetry values (black contour lines) for four individual months. These four monthly composites were chosen because of reduced cloud cover within the South Georgia bloom area. Furthermore, each image provides examples of the major spatial Chl $a$ patterns present in the SeaWiFS time series analysed here and allows an examination of how bloom distributions relate to local circulation. Unsurprisingly, all composites reveal greater patchiness with respect to the previously described $\mathrm{Chl} a$ climatology (Fig. 3, see also Fig. 2 for a climatology of circulation around South Georgia).

In all chosen examples, a close match between Chl $a$ distributions and surface flow fields (direction and intensity) is observed, also at the smaller scales. In December 1998 (Fig. 4a) for example, the phytoplankton bloom is clearly confined to the area comprising the shelf of the island and it extends over the southern and northern sectors of the Georgia Basin up to the southern limit of the Polar Front (bold line), here defined following Venables et al. (2012). All sides of the bloom are tightly contoured by closely spaced isopleths, which indicate strong currents. Similar phytoplankton blooms and circulation patterns are also observed in December 2001, January 2005 and January 2006 (not shown). Over the North West Georgia Rise $\left(37^{\circ} \mathrm{W}, 52.5^{\circ} \mathrm{S}\right)$, amidst Chl $a$ concentrations greater than $2 \mathrm{mg} \mathrm{m}^{-3}$, a patch with lower Chl $a$ values $\left(\sim 0.70 \mathrm{mg} \mathrm{m}^{-3}\right)$ can be observed delineated by closed lines 

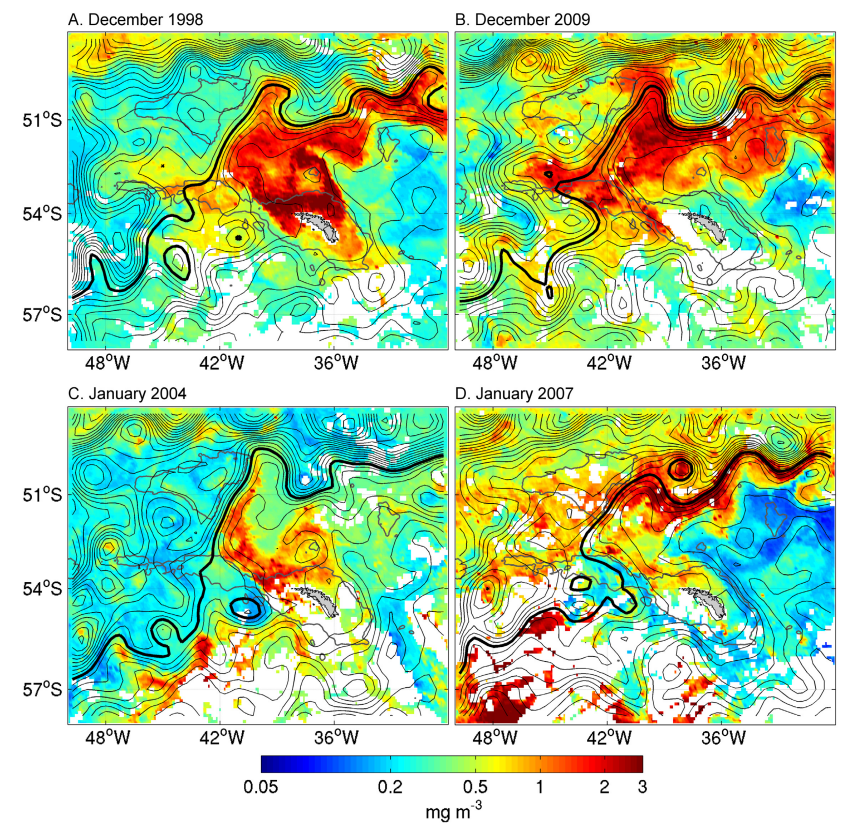

Fig. 4. Monthly composites of Chl $a$ concentrations (colour) and concomitant dynamic topography isopleths (black lines) for (A) December 1998, (B) December 2009, (C) January 2004 and (D) January 2007, respectively. Isopleths are equally spaced every 5 dyn $\mathrm{cm}$ to highlight the smaller scale features; values decrease from north to south. As reference, the $-71 \mathrm{dyn} \mathrm{cm}$ contour is depicted with a bold line, to indicate, according to Venables et al. (2012), the southern limit of the Polar Front. Colour scale units are $\mathrm{mg} \mathrm{m}^{-3}$. Yellow to red colours depict bloom conditions ( $\mathrm{Chl} a \geq 0.75 \mathrm{mg} \mathrm{m}^{-3}$ ). Regions in white correspond to data gaps due to the presence of persistent cloud cover. For reference, the $2000 \mathrm{~m}$ bathymetry contour is also indicated with thin grey lines.

that indicate the presence of the anticyclonic eddy previously identified by Meredith et al. (2003). This eddy is present in most of the summer months considered for this study and is clearly captured by the circulation climatology of Fig. 2 .

Compared to December 1998 (Fig. 4a), the periphery of the bloom observed in December 2009 (Fig. 4b) is less clearly defined and extends further to the west, following the pronounced meander kinking westwards. Most of the bloom is confined to the northern sector of the Georgia Basin and is missing around the island. Other examples of similar Chl $a$ distributions are found in December 1999, January 2003 and December 2007 (not shown). Worth noting, is the anticyclonic eddy present north of the bloom area, with lower Chl $a$ concentrations. This eddy, which is a recurrent feature of the region and is also present in the monthly images of December 2001 and December 2005 (not shown), is likely stabilized by bottom topography, which here is closely followed by the lines of flow (see also Fig. 2). In January 2004 (Fig. 4c) the phytoplankton bloom is much weaker and smaller and is confined to the area closer to the island; highest $\mathrm{Chl} a$ concentrations are found surrounding the North West Georgia Rise and over the northern shelf of the island up to the northern limits of the Maurice Ewing Bank-Georgia Basin (MEBGB) margin. In January 2007 (Fig. 4d), bloom conditions are mostly limited to a narrow band of very closely spaced dynamic topography isopleths to the north of South Georgia, following the approximate position of the Polar Front (bold contour line). In this monthly composite, as in December 2000 (not shown), intense blooms (Chl $a>2 \mathrm{mg} \mathrm{m}^{-3}$ ) are present far from the island shelf and at distances calculated along the direction of main flow that can be greater than $800 \mathrm{~km}$. To the northwest of the island, and over the southern portion of the Georgia Basin Chl $a$ concentrations are mostly below $1 \mathrm{mg} \mathrm{m}^{-3}$ and in the proximity of the North West Georgia Rise Chl $a$ values are close to $0.2 \mathrm{mg} \mathrm{m}^{-3}$. The $\mathrm{Chl} a$ rich cyclonic eddy detaching from the northern tip of the South Georgia bloom is another recurrent feature of the region, and has been observed also in December 2000 and December 2004 (not shown).

Overall, we observe that protrusions and bends in regions of enhanced Chl $a$ values generally coincide with meanders in the flow, while patches of higher or lower concentrations coincide with eddies. In most cases, largest concentration gradients are located along bands of rapid currents, which define the limits of the bloom area. This can be particularly seen along the -71 dyn $\mathrm{cm}$ contour (i.e., the southern limit of the Polar Front, Venables et al., 2012), which in all cases closely delimits the western extent of South Georgia blooms to the MEB-GB margin and determines the formation of the clockwise flowing meander located at the northern tip of the Georgia Basin $\left(39^{\circ} \mathrm{W}, 50^{\circ} \mathrm{S}\right)$. In these locations, the close correspondence between circulation and primary productivity patterns is well captured also by the climatologies depicted in Figs. 2 and 3. Furthermore, particularly recurrent appears to be the flow found along the northern flank of Shag Rocks and travelling from the northwestern shelf of the island towards the MEB-GB margin. In most cases, this particular flow delimits the southwestern extension of phytoplankton blooms occurring over the Georgia Basin.

Summarizing, phytoplankton blooms (i.e., Chl $a$ concentrations greater than $0.75 \mathrm{mg} \mathrm{m}^{-3}$ ) are observed on all occasions and they recur especially over the northern shelf of the island, and in the southwestern portion of the Georgia Basin extending to its northern periphery along the MEB-GB margin. Outside these regions phytoplankton blooms show larger variability. In particular, to the west and to the north of the line delimiting the southern extent of the Polar Front and due east of the island, summer $\mathrm{Chl} a$ concentrations never rise above $0.5 \mathrm{mg} \mathrm{m}^{-3}$.

Occasional small-scale pattern differences between surface flows and Chl $a$ distributions shown in Fig. 4 can be affected by the different spatial resolution of the two datasets $\left(1 / 4^{\circ}\right.$ for Aviso and circa $1 / 12^{\circ}$ for SeaWiFS), or by the temporal average (here we show monthly composites). Such large averaging time period is dictated by the need for enough ocean colour measurements; the latter in fact are highly 
compromised by persistent cloud cover (white regions in the panels of Fig. 4).

\subsection{Frequency of bloom occurrences and the typical bloom area}

Ocean colour estimates utilized to construct the climatological average depicted in Fig. 3 were also elaborated with the pixel count algorithm; results provide information on the frequency of occurrence of summer phytoplankton blooms recorded in the South Georgia region. The colour of each image-pixel $\left(\sim 60 \mathrm{~km}^{2}\right)$ represents the total number of years when $\mathrm{Chl} a$ concentrations exceeded $0.75 \mathrm{mg} \mathrm{m}^{-3}$ (i.e., bloom conditions).

In the South Georgia region, the area where blooms occurred in at least 8 out of the $12 \mathrm{yr}$ (coloured with shades of red) is largely confined to the Georgia Basin and the northern shelf of the island, with highest values close to the western and northern periphery of the basin (FBO equal or greater than 10). Worth noting are the presence of high FBO also at the northernmost tip of the Georgia Basin $\left(39^{\circ} \mathrm{W}, 50^{\circ} \mathrm{S}\right)$ which has often been excluded from ocean colour and in situ investigations. Bloom conditions were more variable over Shag Rocks and the southern shelf of South Georgia, where FBO values mostly range between 4 and 7. Furthermore, FBO ranging between 1 and 4 indicate that summer blooms have occurred also south of the island, although only on few occasions (pixels coloured in shades of green and blue). Just outside the periphery of the Georgia Basin, especially to the west and north of the basin, as well as along the eastern shelf of the island, frequency values remain very low $(\mathrm{FBO}<2)$, indicating that in almost all years blooms were absent.

Utilization of the pixel count algorithm with the objective to locate and enumerate the occurrence of $\mathrm{Chl} a$ concentrations greater than $0.75 \mathrm{mg} \mathrm{m}^{-3}$ in 12 summer seasons, has allowed for identifying a sector of the South Georgia region in which phytoplankton blooms have been most recurrent (FBO equal or greater than 8), and where, therefore, blooms can be considered predictable in time. This region, which we consider to be representative of South Georgia phytoplankton blooms, and which we hereafter refer to as the typical bloom area, has been outlined in Fig. 5 (dotted black line) but also in Fig. 3 (solid grey line) to allow a comparison with the Chl $a$ climatology described above (Sect. 3.1). The results on temporal variability of surface $\mathrm{Chl} a$ concentrations and phytoplankton blooms shown below (Figs. 6 and 7) are restricted to this area.

The typical bloom area defined by applying the pixel count algorithm agrees in shape with the area of enhanced $\mathrm{Chl} a$ concentrations indicated in the summer climatology (Fig. 3). Similarly in both the frequency plot and in the Chl $a$ climatology, the core of the South Georgia bloom is found to the northwest of the island and is centred over the deep waters of the Georgia Basin (depths greater than 3000 m, Fig. 2); moreover, in both cases there is a clear indication of the nar-

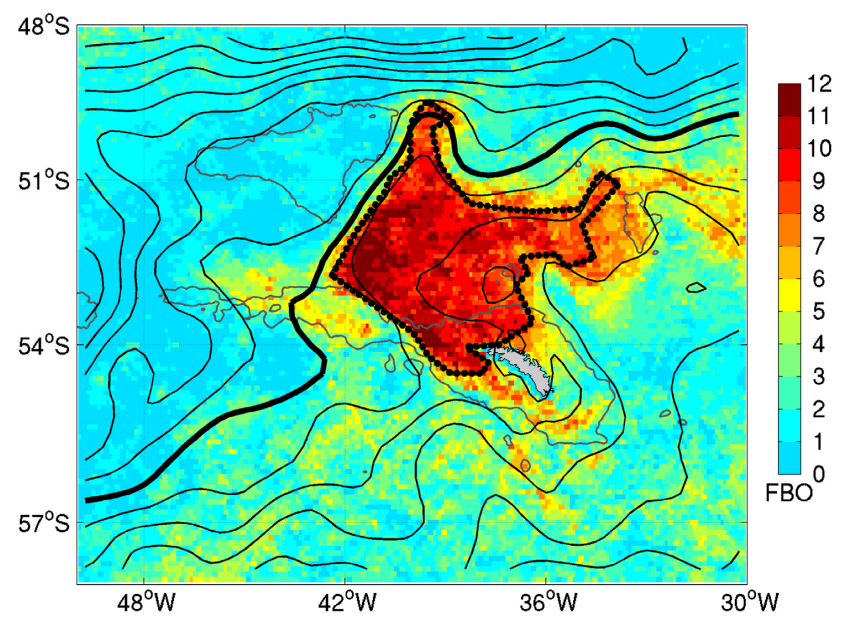

Fig. 5. Phytoplankton bloom occurrences in the South Georgia region obtained from SeaWiFS estimates and calculated for austral summer (December-February, from 1997-2010). Colour indicates the frequency of occurrence of bloom conditions (Chl $a \geq 0.75 \mathrm{mg} \mathrm{m}^{-3}$ ). Regions coloured in shades of red correspond to pixels where summer blooms have been recorded at least 8 times out of the 12 sampled seasons while regions in shades of blue indicate more rare bloom events. Black lines correspond to Aviso dynamic topography isopleths for the summer climatology (December-February, from 1997-2010); isopleths are drawn every $10 \mathrm{dyn} \mathrm{cm}$. For reference, the bold black line corresponds to -71 dyn $\mathrm{cm}$, and is indicated by Venables et al. (2012) as the southern limit of the Polar Front. The polygon drawn with a dotted black line indicates the extension of the typical bloom area. The $2000 \mathrm{~m}$ bathymetry contour is also indicated.

row bloom protrusion extending north of the $50^{\circ} \mathrm{S}$ parallel $\left(39^{\circ} \mathrm{W}, 50^{\circ} \mathrm{S}\right)$.

However, as only regions characterized by FBO greater or equal to 8 were considered in the successive steps of our analysis, most of the southern and eastern shelf of the island, as well as the area surrounding Shag Rocks and the area adjacent to the North East Georgia Rise were not included in the typical bloom area. Although in these latter regions the $\mathrm{Chl} a$ climatology averages are above $0.75 \mathrm{mg} \mathrm{m}^{-3}$, frequency calculations indicate that phytoplankton blooms have occurred less regularly or only on few occasions; this is especially valid for the area over Shag Rocks, where FBO are mostly close to or below 6. Portions of the South Georgia region where climatological Chl $a$ averages indicate values below $0.75 \mathrm{mg} \mathrm{m}^{-3}$ (areas shaded in green and blue) are never part of the typical bloom area.

The typical bloom area $\left(\sim 145000 \mathrm{~km}^{2}\right)$ contains the bloom region shown by Korb et al. (2008), but includes the area lying north of $50^{\circ} \mathrm{S}$, where FBO indicate recurrent summer phytoplankton blooms. It is important to note that the typical bloom area differs considerably from the South Georgia area illustrated by Park et al. (2010) (outlined in their Fig. 5a, and in Fig. 3 of the present contribution), which was 

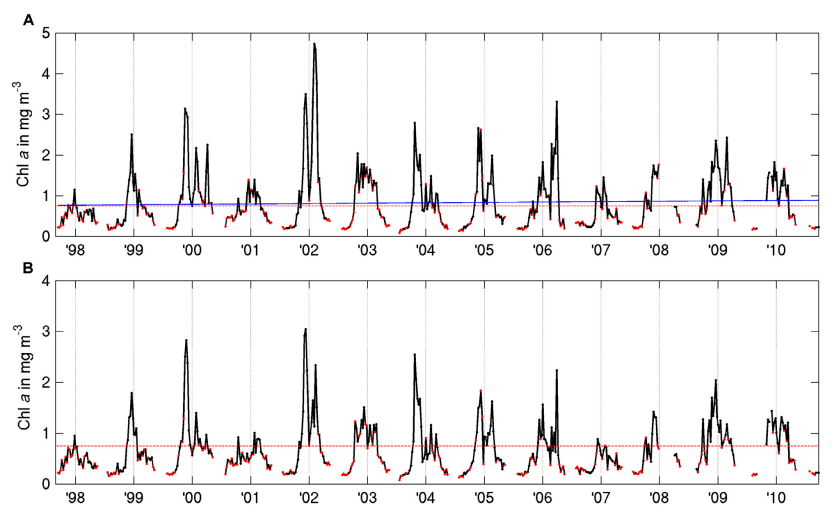

Fig. 6. Chl $a$ time series obtained from the mean (A) and the median (B) of all Chl $a$ values available from eight-day composites of the typical bloom area between September 1997 and September 2010. In (A) the regression line calculated along time is illustrated in blue. In both cases, as pixels with no data were excluded, we distinguish values that were obtained from more (black) or less (red) than $30 \%$ of all pixels contained in the typical bloom area. Between 9 January and 28 March 2008 no SeaWiFS data were available. Chl $a$ concentrations are expressed in $\mathrm{mg} \mathrm{m}^{-3}$. Vertical grid-lines indicate the first week of each year. The dashed red horizontal lines denote $0.75 \mathrm{mg} \mathrm{m}^{-3}$.

obtained from an empirical orthogonal function analysis and k-means classification. Compared to the typical bloom area, their area was centred on South Georgia and hence excluded the northern portion of the Georgia Basin, and included the low chlorophyll waters found to the southwest and east of the island. The sensitivity of the $\mathrm{Chl} a$ concentration time series on the specific area under consideration is discussed in Sect. 4.

\subsection{Temporal variability across the typical bloom area}

All SeaWiFS eight-day Chl $a$ values between September 1997 and September 2010 were averaged over the typical bloom area to construct the time series shown in Fig. 6a. For comparison with previous work, we also constructed a time series based on the median of the above Chl $a$ values (Fig. 6b). Pixels with no data were excluded from the calculations. Chl $a$ average and median values that were obtained from less than $30 \%$ of all pixels included in the typical bloom area are marked with red dots in Fig. 6. Cloud cover, especially between late March and the first weeks of September, and low light levels between June and July are the main causes of reduced data coverage. The time series of average and median values are very similar, hence in the following we considered only average values. In order to investigate at greater detail the seasonal and intra-seasonal variability of phytoplankton blooms, in the second step of our analysis the time series obtained from Chl $a$ averages (Fig. 6a) was split into separate seasons (coloured lines in Fig. 7a). The time
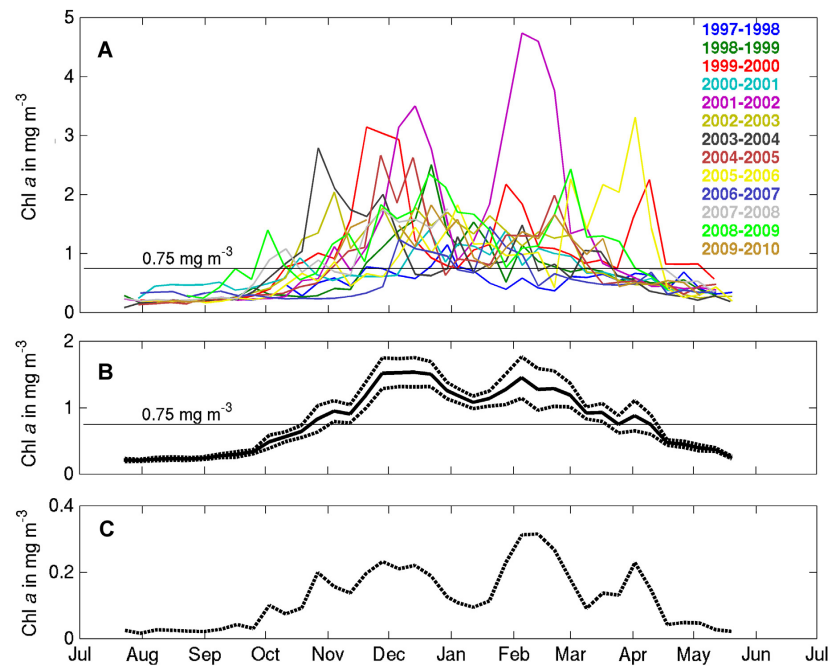

Fig. 7. Seasonal variability of Chl $a$ concentrations and bloom occurrences in the typical bloom area. (A) Every year included between September 1997 and June 2010 is colour-coded differently; refer to Fig. 6 for data-coverage in each data-point and Table 1 for growth-season Chl $a$ averages and bloom duration. (B) Chl $a$ concentration climatological average (solid line) and the one standard error interval (dashed line) as obtained from all curves depicted in panel A. (C) The dashed line indicates the one standard error interval (as in panel B). Horizontal black lines in panels A and B mark $0.75 \mathrm{mg} \mathrm{m}^{-3}$.

series of Chl $a$ concentrations was also used to derive the regression line depicted in blue in Fig. $6 \mathrm{a}$.

Despite the pronounced inter-annual variability in the time series shown in Fig. 6a, phytoplankton blooms (i.e., Chl $a \geq 0.75 \mathrm{mg} \mathrm{m}^{-3}$ ) occurred every year. Concentrations above $2 \mathrm{mg} \mathrm{m}^{-3}$ were reached in $7 \mathrm{yr}$, with values exceeding $3 \mathrm{mg} \mathrm{m}^{-3}$ in November 1999, December 2001 and February 2002, as well as in April 2006. Least productive growth seasons were in 1997/1998, 2000/2001 and 2006/2007 (see also Table 1 ). The very small slope of the regression line $\left(0.009 \pm 0.01 \mathrm{mg} \mathrm{m}^{-3} \mathrm{yr}^{-1}\right.$, blue line in Fig. 6a) indicates that in the time period analysed here, Chl $a$ concentrations did not follow an evident long term temporal trend.

The annual cycle of average Chl $a$ concentrations over the typical bloom area and the timing of the phytoplankton blooms is given for each year in Fig. 7a, together with the climatological annual cycle (solid bold black line in Fig. 7b) and the one standard error interval (dashed black lines in Fig. 7b). The one standard error interval is depicted also in Fig. $7 \mathrm{c}$ to allow for greater detail. Additionally, Table 1 provides for each year as well as for the climatological annual curve the phytoplankton bloom duration (expressed as the first and last week in which calculated $\mathrm{Chl} a$ averages were $\geq 0.75 \mathrm{mg} \mathrm{m}^{-3}$ ) and the total number of days in which Chl $a$ concentrations averaged over the typical bloom area were $\geq 0.75 \mathrm{mg} \mathrm{m}^{-3}$. In addition, for each year are also indicated the Chl $a$ value and the date of the week when the season's 
Table 1. Column 2 and 3: phytoplankton bloom duration; Column 4: growth-season's maximum Chl $a$ value and its timing (date of week); Column 5: year's specific seasonal Chl $a$ average (based on the growth-season durations indicated in Column 2); Column 6: Chl $a$ seasonal average based on the average growth-season length (i.e., from 27 October to 02 April). All concentrations values are expressed in mg $\mathrm{m}^{-3}$.

\begin{tabular}{llrrrr}
\hline Year & $\begin{array}{c}\text { Date of first and last week } \\
\text { when Chl } a \geq 0.75 \mathrm{mg} \mathrm{m}^{-3}\end{array}$ & $\begin{array}{r}\text { Days with Chl } a \\
\geq 0.75 \mathrm{mg} \mathrm{m}^{-3}\end{array}$ & $\begin{array}{r}\text { Value and date of } \\
\text { maximum Chl } a\end{array}$ & $\begin{array}{r}\text { Growth-season } \\
\text { Chl } a \text { average } \\
\text { (year specific) }\end{array}$ & $\begin{array}{r}\text { Growth-season } \\
\text { Chl } a \text { average } \\
\text { (27 Oct-02 Apr) }\end{array}$ \\
\hline 1997/1998 & 20 Nov 1997-04 Jan 1998 & 32 & $1.15 / 30$ Dec 1997 & 0.78 & 0.62 \\
$1998 / 1999$ & 20 Nov 1998-21 Feb 1999 & 96 & $2.51 / 22$ Dec 1998 & 1.22 & 0.96 \\
$1999 / 2000$ & 11 Oct 1999-03 May 2000 & 208 & $3.14 / 20$ Nov 1999 & 1.34 & 1.42 \\
$2000 / 2001$ & 18 Oct 2000-01 Mar 2001 & 96 & $1.4 / 28$ Jan 2001 & 0.91 & 0.87 \\
$2001 / 2002$ & 04 Nov 2001-17 Mar 2002 & 136 & $4.73 / 05$ Feb 2002 & 2.19 & 1.97 \\
$2002 / 2003$ & 19 Oct 2002-01 Mar 2003 & 144 & $2.04 / 04$ Nov 2002 & 1.45 & 1.18 \\
$2003 / 2004$ & 11 Oct 2003-16 Mar 2004 & 120 & $2.79 / 27$ Oct 2003 & 1.34 & 1.15 \\
$2004 / 2005$ & 03 Nov 2004-09 Mar 2005 & 128 & $2.67 / 27$ Nov 2004 & 1.31 & 1.21 \\
$2005 / 2006$ & 04 Nov 2005-10 Apr 2006 & 136 & $3.31 / 02$ Apr 2006 & 1.03 & 0.69 \\
$2006 / 2007$ & 06 Dec 2006-05 Feb 2007 & 56 & $1.45 / 20$ Jan 2007 & 1.3 \\
$2007 / 2008$ & 03 Oct 2007-N/A & $>72$ & $1.76 / 30$ Dec 2007 & 1.37 & 1.47 \\
$2008 / 2009$ & 02 Oct 2008-02 Apr 2009 & 176 & $2.43 / 01$ Mar 2009 & 1.2 \\
$2009 / 2010$ & 04 Nov 2009-17 Mar 2010 & 136 & $1.82 / 22$ Dec 2009 & 1.19 & 1.19 \\
\hline Average & 27 Oct-02 Apr & 160 & $1.53 / 14$ Dec & & \\
\hline
\end{tabular}

maximum value was recorded, as well as the growth-season Chl $a$ average.

As described above and depicted in Figs. 6 and 7a, Chl a concentrations reach phytoplankton bloom levels in all years. Typically, until late winter or early spring (i.e., mid-September) averaged $\mathrm{Chl} a$ values remain low $\left(\leq 0.2 \mathrm{mg} \mathrm{m}^{-3}\right)$; after September Chl $a$ concentrations increase progressively and in most cases peak between midNovember and the end of December, although austral spring peaks are observed also earlier in the season, as in October 2008, October 2003 or November 2002 (1.4, 2.8 and $2.04 \mathrm{mg} \mathrm{m}^{-3}$, respectively). After the spring peaks terminate, as is occurring in most cases by the beginning of January, Chl $a$ values gradually decrease and by the beginning of April (exceptions are April 2006 and April 2000) fall below $\sim 0.75 \mathrm{mg} \mathrm{m}^{-3}$. During the first weeks of May Chl $a$ concentrations are very low, except in May 2000 and May 2005 when concentrations were still close to $0.4 \mathrm{mg} \mathrm{m}^{-3}$. In contrast with this progressive decrease in Chl $a$ concentrations, during several years, and especially between late summer and early autumn, a second or even a third intense peak in Chl $a$ values (Chl $a>2 \mathrm{mg} \mathrm{m}^{-3}$ ) was observed (i.e., in the seasons of 2001/2002, 2008/2009, 1999/2000 or 2004/2005). At times, the second peak appears to be more intense than the preceding spring peak. In particular, a total of three Chl $a$ concentration peaks were observed in the 1999/2000 season (red curve in Fig. 7a), at the end of November 1999, during late January/early February 2000 and in April 2000, respectively. Between mid-May and mid-July, the very low light levels preclude satellite estimates of winter Chl $a$ concentrations.
Comparison between each seasonal curve and the chosen threshold (black horizontal line in Fig. 7a) indicates that in 9 out of $12 \mathrm{yr}$, phytoplankton blooms lasted more than four months (see also Table 1). The shortest phytoplankton bloom seasons were recorded during the 1997/1998 and the 2006/2007 seasons, when phytoplankton bloom conditions were maintained for less than three months (Table 1).

The climatological growth season, obtained after averaging all years considered in this study, is characterized by two distinct productivity peaks (Fig. 7b). The first Chl $a$ peak $\left(\sim 1.52 \mathrm{mg} \mathrm{m}^{-3} \pm 0.21 \mathrm{mg} \mathrm{m}^{-3}\right)$ is recurrent and occurred regularly between late November and the first weeks of December. The second peak $\left(\sim 1.38 \mathrm{mg} \mathrm{m}^{-3} \pm 0.31 \mathrm{mg} \mathrm{m}^{-3}\right)$ instead, is a less regular feature (both in timing and magnitude) and occurred between late January and early April. A transition phase, included between the last week of December and mid-January, can be observed between the peaks. Just before this trough, which appears as a regular feature of the seasonal cycle (standard error interval $\sim 0.1 \mathrm{mg} \mathrm{m}^{-3}$, Fig. 7c), spring Chl $a$ concentrations declined by about $30 \%$, from $1.52 \mathrm{mg} \mathrm{m}^{-3}$ to $1.08 \mathrm{mg} \mathrm{m}^{-3}$.

\section{Discussion}

The trajectories of the Polar Front and the Southern ACC Front in the South Georgia region (Venables et al., 2012; Park et al., 2010) together with the patterns of local circulation (Figs. 2 and 4) play a major role in controlling the location and extension of the blooms which develop to the north and northwest of the island and tend to reflect the geometry of the Georgia Basin. In particular, the southern limit of the 
Polar Front, identified following Venables et al. (2012), and the flow that travels westward from the northern shelf of the island along the northern flank of Shag Rocks generally separated bloom from impoverished waters outside the Georgia Basin. Hence, the boundaries of the typical bloom area are clearly demarcated and vary little over time because the flow field is constrained by bottom topography.

The veritable absence of blooms along the eastern shelf of the island and their recurrence to the west and far north of the typical bloom area can be explained by rapid transport of island and shelf-derived iron by intense currents (20$40 \mathrm{~cm} \mathrm{~s}^{-1}$; Ward et al., 2005) that flow to the northwest of the island and subsequently turn east. This circulation regime explains, e.g., the distribution of enhanced $\mathrm{Chl} a$ concentrations in Fig. 4c, where highest concentrations are found along the western periphery of the basin up to the northern limits of the MEB-GB margin. The importance of hydrography in controlling the extent of South Georgia phytoplankton blooms has been reported at the climatological level (i.e., Park et al., 2010) or for averages of a few years (Venables et al., 2012), but not at the high temporal and spatial resolution over $13 \mathrm{yr}$ that we present here.

Phytoplankton blooms always occurred within the typical bloom area but their locations, intensities and time of onset (i.e., first week in which Chl $a$ were $\geq 0.75 \mathrm{mg} \mathrm{m}^{-3}$, Table 1) exhibited pronounced inter-annual variability. This is not surprising given the various independent factors that can influence surface $\mathrm{Chl} a$ concentrations. Among these: mixed layer depth and its effects on bloom dilution (Smetacek and Naqvi, 2008), dust input (e.g., Gassó et al., 2010), composition of the bloom (diatoms versus flagellates) and grazing (Whitehouse et al., 2009). Variations in flow intensity and pathways of the ACC fronts around South Georgia (Thorpe et al., 2002; Park et al., 2010; Boehme et al., 2008) are also among the most important factors likely influencing the interannual variability of the bloom: circulation around and then downstream of shallow topographic features is believed to control the magnitude of sediment-derived iron input to the water column (i.e., due to re-suspension processes) as well as its transport to more distant regions (Blain et al., 2008; de Jong et al., 2012; Nishioka et al., 2011; Planquette et al., 2007).

In particular, we investigated the roles of SST, PAR and wind speed in regulating the observed inter-annual variability. Growth-season averages (i.e., from 27 October to 02 April, in Table 1) of each environmental variable were correlated with those obtained from $\mathrm{Chl} a$ concentrations. All growth-season averages used in the correlations as well as the obtained correlation coefficients are reported in Table 2. The positive correlation coefficients we obtained for Chl $a / \mathrm{SST}$ $(R=0.48, n=10)$ and for Chl $a / \mathrm{PAR}(R=0.24, n=13)$, indicate the positive effect of warmer temperatures, which likely reflect a shallower mixed layer depth, and higher PAR levels on surface $\mathrm{Chl} a$ concentrations. For example, the presence of warmer temperatures and higher PAR levels could explain the particularly high $\mathrm{Chl} a$ concentration averages during the 2001-2002 season (Fig. 6). Conversely, no relationship was found between Chl $a$ and wind speed $(R \sim 0$, $n=10)$; this is likely because of the pronounced irregularity of wind speeds over the typical bloom area during summer (wind speed time series not shown). When we analysed the correlations of SST, PAR and wind speed with the timing of bloom onset (values in Table 2), we found negative correlation coefficients, i.e., $R=-0.19, n=10$ for date of onset/SST and $R=-0.37, n=13$ for date of onset/PAR; these negative values indicate that phytoplankton blooms started earlier in years when SST and PAR levels were higher than the respective climatologies. Conversely, the correlation between the date of bloom onset and wind speed is inconclusive because the correlation coefficient is negative or positive depending on the number of pairs used in the correlation (i.e., $R=-0.30, n=10$ and $R=0.12, n=9$ ).

The expected intrinsic variability of top-down and bottomup controls, as well as the fact that these may have additive or contrasting effects on pigment biomass accumulation, as would be the case for the controls mentioned above, may explain the absence of a prominent decadal trend in the Chl $a$ time series (Fig. 6a). Similar conclusions were reached by Arrigo et al. (2008) who analysed annual primary production in the Southern Ocean. However, the very small yet positive slope of the regression line $\left(0.009 \pm 0.01 \mathrm{mg} \mathrm{m}^{-3} \mathrm{yr}^{-1}\right)$ that suggests a slow increase in Chl $a$ concentrations (i.e., $0.09 \mathrm{mg} \mathrm{m}^{-3}$ in ten years), appears to be in line with Whitehouse et al. (2008b) who expected an increase in productivity as a response to the gradual warming documented around South Georgia.

Pronounced variability in Chl $a$ concentrations around South Georgia was also reported by Park et al. (2010). They used ocean colour estimates from SeaWiFS for the period September 1997-December 2007 and ocean colour estimates from MODIS for the period January 2008-August 2008. They applied an empirical orthogonal function analysis to the $11 \mathrm{yr}$-period of satellite observations and then used the kmeans algorithm to delimit, among others, a polygonal area around South Georgia (outlined in their Fig. 5a, and in Fig. 3 of the present contribution); across this area they studied temporal patterns of $\mathrm{Chl} a$ concentrations.

Their results showed that in only six of the 11 yr-period, Chl $a$ concentrations exceeded $0.75 \mathrm{mg} \mathrm{m}^{-3}$ and that in all cases they remained below $2 \mathrm{mg} \mathrm{m}^{-3}$. Our time series, based on average or median values (Fig. 6a and b) provide a different picture, indicating bloom levels in all years and $\mathrm{Chl} a$ concentrations exceeding $2 \mathrm{mg} \mathrm{m}^{-3}$ in at least five years.

Differences between the typical bloom area and the South Georgia area used by Park et al. (2010) are most likely causing these contrasting results (both areas are outlined in Fig. 3). While the typical bloom area is located to the north and northwest of the island only, where phytoplankton blooms are pronounced and most recurrent (i.e., over the Georgia Basin), the area defined by Park et al. (2010) 
Table 2. SST, PAR and wind speed growth-season averages (from 27 October to 02 April) and 15-day anomalies prior to each year's date of bloom onset. Coefficients obtained from their correlations with the Chl $a$ growth-season average (in Column 2) and the date of bloom onset (in Column 3) are also reported.

\begin{tabular}{|c|c|c|c|c|c|c|c|c|}
\hline \multirow[t]{2}{*}{ Year } & \multirow{2}{*}{$\begin{array}{l}\text { Chl } a \text { growth- } \\
\text { season } \\
\text { average }\end{array}$} & \multirow[t]{2}{*}{$\begin{array}{l}\text { Date of } \\
\text { bloom onset }\end{array}$} & \multicolumn{2}{|c|}{$\operatorname{SST}\left({ }^{\circ} \mathrm{C}\right)$} & \multicolumn{2}{|c|}{$\begin{array}{c}\text { PAR (mol } \\
\left.\text { photons } \mathrm{m}^{-2} \mathrm{~d}^{-1}\right)\end{array}$} & \multicolumn{2}{|c|}{$\begin{array}{l}\text { Wind Speed } \\
\qquad\left(\mathrm{m} \mathrm{s}^{-1}\right)\end{array}$} \\
\hline & & & $\operatorname{avg}^{1}$ & $15-$ day $^{2}$ & $\operatorname{avg}^{1}$ & $15-$ day $^{2}$ & $\operatorname{avg}^{1}$ & $15-$ day $^{2}$ \\
\hline 1997-1998 & 0.62 & 20 Nov 1997 & N/A & N/A & 33.26 & -6.51 & N/A & N/A \\
\hline 1998-1999 & 0.96 & 20 Nov 1998 & N/A & N/A & 34.98 & -3.23 & N/A & N/A \\
\hline 1999-2000 & 1.42 & 11 Oct 1999 & N/A & N/A & 32.22 & 1.58 & 9.1 & 0.22 \\
\hline 2000-2001 & 0.87 & 18 Oct 2000 & 2.75 & -0.09 & 33.78 & 3.93 & 9.49 & -0.68 \\
\hline 2001-2002 & 1.97 & 04 Nov 2001 & 3.64 & -0.27 & 35.68 & 1.26 & 9.27 & 1.33 \\
\hline 2002-2003 & 1.29 & 19 Oct 2002 & 2.71 & -0.56 & 33.67 & -1.67 & 8.97 & -0.37 \\
\hline 2003-2004 & 1.15 & 11 Oct 2003 & 3.63 & 0.1 & 35.06 & -0.81 & 9.18 & -0.24 \\
\hline 2004-2005 & 1.21 & 03 Nov 2004 & 3.63 & 0.22 & 35.54 & 2.61 & 9.14 & 0.62 \\
\hline 2005-2006 & 1.27 & 04 Nov 2005 & 3.17 & -0.4 & 35.44 & -0.92 & 8.62 & -1.78 \\
\hline 2006-2007 & 0.69 & 06 Dec 2006 & 3.27 & 0.06 & 35.37 & -2.63 & 8.99 & -1.62 \\
\hline 2007-2008 & 1.3 & 03 Oct 2007 & 3.08 & 0.2 & 39.6 & -0.56 & 8.97 & 0.15 \\
\hline 2008-2009 & 1.47 & 02 Oct 2008 & 3.77 & 0.38 & 35.87 & 4.77 & 9.04 & -0.72 \\
\hline 2009-2010 & 1.2 & 04 Nov 2009 & 3.07 & 0.18 & 35.15 & 10.46 & N/A & N/A \\
\hline \multicolumn{3}{|c|}{ Correlation coeff. for growth-season averages } & 0.48 & & 0.24 & & -0.007 & \\
\hline \multicolumn{3}{|c|}{ Correlation coeff. with date of bloom onset } & & $\begin{array}{r}-0.19 \\
(-0.39)^{3}\end{array}$ & & $\begin{array}{r}-0.37 \\
(-0.30)^{3}\end{array}$ & & $\begin{array}{r}-0.3 \\
(0.12)^{3}\end{array}$ \\
\hline
\end{tabular}

occupies the southwestern portion of the Georgia Basin and includes waters to the southwest and east of the island, where Chl $a$ values are generally below $0.5 \mathrm{mg} \mathrm{m}^{-3}$ and in some months even as low as $0.2 \mathrm{mg} \mathrm{m}^{-3}$ (i.e., in January 2007). Therefore, their analysis did not include the phytoplankton blooms occurring over the northern and eastern portion of the Georgia Basin, such as those observed in December 1998, December 2009 or January 2007 (Fig. 4), and introduced a systematic negative bias by including the impoverished waters to the southwest and east of the island. Consequently, differences between their time series and the one presented here are more pronounced when maximum $\mathrm{Chl} a$ concentrations were recorded only over the northern sector of the Georgia Basin, as in 2005/2006 and 2006/2007. Hence, the area across which Chl $a$ concentrations are extracted is of critical importance and averaging areas that differ significantly from the typical bloom area can yield different conclusions on the recurrence of phytoplankton blooms but also on their annual cycle.

Phytoplankton dynamics in the Southern Ocean are characterized by a pronounced annual cycle with a growth and non-growth season constrained by the combined effects of the solar cycle, shallowing and deepening of mixed layer depth and timing of sea-ice retreat and advance (Smith et al., 2008; Venables and Moore, 2010). Chl $a$ concentrations peaks have been observed in the first half of the growth sea- son, while in the second half concentrations were progressively lower, resulting in a unimodal pattern mostly centred between late spring and early summer (Mongin et al., 2008; Moore and Abbott, 2000; Thomalla et al., 2011). Conversely, over the typical bloom area $\mathrm{Chl} a$ concentrations remained high throughout the entire growing seasons, and in many years followed a bimodal pattern.

Double Chl $a$ concentration peaks are well known for the North Atlantic phytoplankton growth season (Martinez et al., 2011) but to our knowledge have been reported only on few occasions from the open Southern Ocean (Trull et al., 2001; Jouandet et al., 2011). Trull et al. (2001) reported a double peak in the subantarctic zone south of Australia for the 1997/1998 season only, while Jouandet et al. (2011) observed two regular peaks in the Kerguelen Plateau phytoplankton bloom over the period between October 1997 and October 2007. Jouandet et al. (2011) observed a first peak in late spring (i.e., between November and December), and a second peak mostly around January. Over the typical bloom area the timing of the first $\mathrm{Chl} a$ concentration peak occurred mostly around December, similarly to the first Chl $a$ peak in the Kerguelen region. However, as observed in Fig. 7, the second bloom peak reported over the typical bloom area exhibited higher variability in timing but also magnitude than the first peak, presumably due to variability in the factors responsible for its build-up. Amongst these we exclude light 
levels, which are sufficient to support pigment biomass accumulation until mid-May (Venables and Moore, 2010), but also mixed layer depth, which according to available climatologies (i.e., Monterey and Levitus, 1997; Dong et al., 2008) remains shallow until the end of April ( $<70 \mathrm{~m})$. Hence, variability in nutrient availability as shown in Fig. 8 below is likely to play the major role.

Iron input and availability is one of the major factors influencing build-up of phytoplankton blooms in the Southern Ocean (Martin et al., 1990; Blain et al., 2008; Boyd et al., 2007). The main sources of iron to the typical bloom area are: dust (Gassó et al., 2010), sediment input from the island or from the deeper enriched layers, through horizontal and vertical advection (Holeton et al., 2005; Nielsdóttir et al., 2012), island runoff and glacial melt (Korb et al., 2008; Young et al., 2011). Dust events from South America are sporadic, likely increasing in austral summer (Gassó et al., 2010), whereas the input of sediment-derived iron could be considered relatively steady because dependant on circulation; the flow originating from the northwestern shelf of the island and travelling westward along the northern flank of Shag Rocks and then along the MEB-GB margin shows in fact reduced variability (see Fig. 4 and Korb et al., 2008). Hence, of the three iron sources only runoff is expected to have a pronounced seasonality during the growth season, with its peak coinciding with maximum rate of ice melt in mid-summer when Chl $a$ concentrations actually tend to decline. Therefore, because several concomitant mechanisms can be proposed as supplying iron to the typical bloom area during austral summer, one could expect iron-replete conditions (see also Nielsdóttir et al., 2012; Hinz et al., 2012).

In order to examine the role of macronutrient availability during the growth season, we present in Fig. 8 surface $(0-50 \mathrm{~m})$ nutrient concentrations for the typical bloom area from the World Ocean Database 2009. Although phosphate and nitrate concentrations vary greatly, they are always high and can be excluded as a limiting factor (Fig. 8a and b). However, silicate concentrations decrease rapidly after October and reach limiting values between December and January (Fig. 8c).

Because the spring bloom is dominated by diatoms (Korb et al., 2008, 2010, 2012) silicate exhaustion is the most likely cause of bloom termination reflected in the January minimum. Groups other than diatoms, e.g., Phaeocystis or coccolithophorids, that could thrive under silicate limiting conditions and potentially form the second bloom also contribute to Southern Ocean blooms, e.g., in the Ross Sea (Arrigo et al., 1999) and in the Crozet region (Poulton et al., 2007), but were rare or have not been reported from the South Georgia region (Korb et al., 2008, 2012). These groups seem more susceptible to virus infection and grazing by zooplankton and krill than diatoms (Smetacek et al., 2004), however, interannual variation in grazing pressure could result in build-up of their biomass and account for the $\mathrm{Chl} a$ increase observed
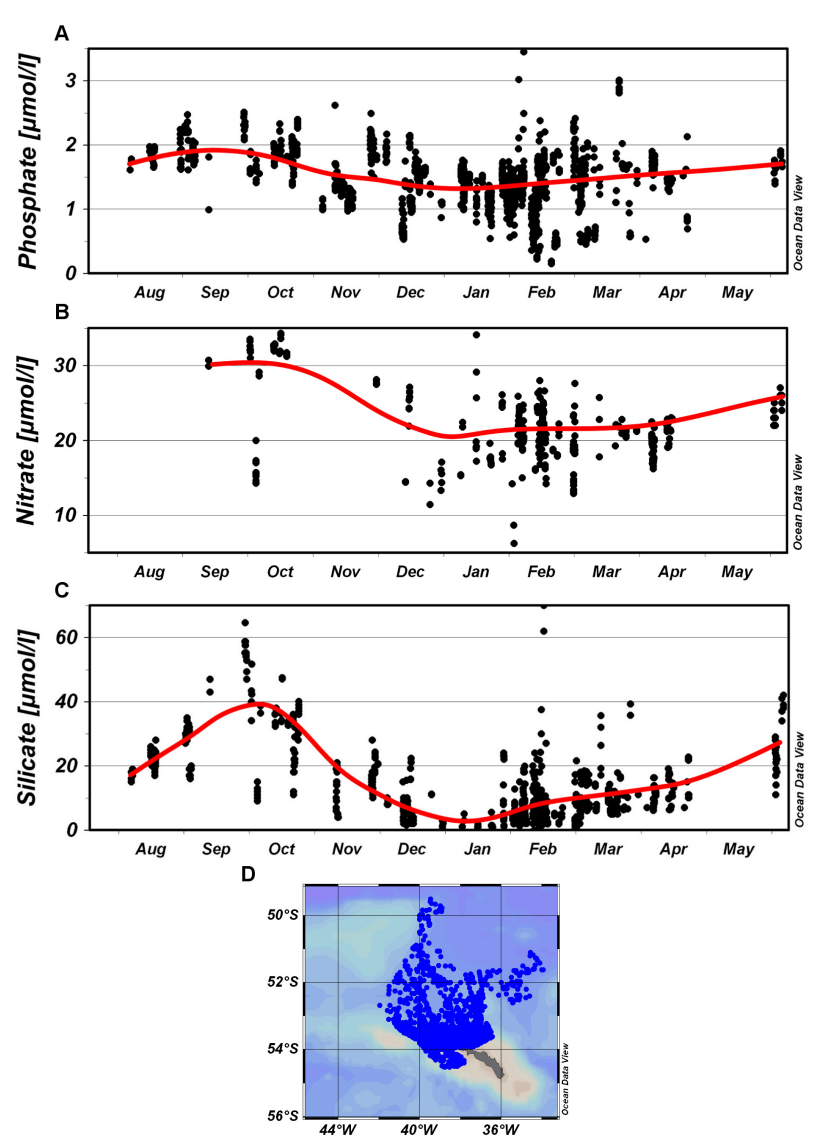

Fig. 8. Seasonal cycle of phosphate (A), nitrate (B) and silicate (C) in the typical bloom area (D). All values are from the surface layer $(0-50 \mathrm{~m})$ and were extracted from the World Ocean Database 2009 (Boyer et al., 2009). In all panels black dots indicate individual original measurements, while red lines represent running averages. All panels were created using Ocean Data View (Schlitzer, 2012).

in the second half of the growth season during some years. This needs to be verified by future ship-based investigations.

It is also possible that the moderate to high $\mathrm{Chl} a$ concentrations in the second phase of the growth season is due to diatoms responding to the progressive increase in silicate concentrations recorded after January (Fig. 8c). The sources of silicate at this time of the growth season could be due to deeper intrusions of SACCF water into the Georgia Basin (Korb et al., 2008; Boehme et al., 2008) but also due to a likely increasing number of end-summer storms, which would favour mixing of surface waters with the deeper enriched ones. Reduced uptake of silicate upstream of the island, where phytoplankton blooms are short lived and terminate earlier in the season depending on iron availability (Whitehouse et al., 2012), could also have an effect on the amount of silicate advected in the typical bloom area.

Because data coverage in ocean colour and nutrient measurements in the typical bloom area are not concomitant nor at equal resolution, the processes responsible for the 
characteristic double peak in Chl $a$ concentrations remain uncertain and need more direct investigations. Indeed, a silicate/iron co-limitation cannot be excluded, especially farther downstream of South Georgia where iron concentrations can be two orders of magnitude lower than those measured over the shelf (Nielsdóttir et al., 2012).

The progressive increase of $\mathrm{Chl} a$ concentrations in spring followed by several months of high phytoplankton biomass (Fig. 7) is likely to reflect the rate of dissolved inorganic carbon (DIC) consumption, and the consequent enhancement of $\mathrm{CO}_{2}$ uptake from the atmosphere. Progressive reduction of $\mathrm{CO}_{2}$ fugacity and DIC with increasing surface Chl $a$ concentrations has been reported for the Kerguelen Plateau region (Lourantou and Metzl, 2011; Jouandet et al., 2008), the Crozet Plateau (Bakker et al., 2007) as well as downstream of South Georgia (Jones et al., 2012; Boutin and Merlivat, 2009). In particular, Jones et al. (2012) estimated a summertime (February 2008) DIC deficit of $4.4 \pm 0.8 \mathrm{Tg} \mathrm{C}$ when the bloom was about $80000 \mathrm{~km}^{2}$ in size, equivalent to $\sim 55 \%$ of the typical bloom area $\left(\sim 145000 \mathrm{~km}^{2}\right)$. Therefore, one would expect that the summertime DIC deficit estimated by Jones et al. (2012) is likely to be a low estimate of the $\mathrm{CO}_{2}$ drawdown that would derive when particularly intense phytoplankton blooms occupied the entire typical bloom area (i.e., December 1998 in Fig. 4a).

\section{Conclusions}

The time series of Chl $a$ concentrations averaged across the typical bloom area $\left(\sim 145000 \mathrm{~km}^{2}\right)$ shows that the South Georgia phytoplankton bloom, defined by $\mathrm{Chl} a$ values $\geq 0.75 \mathrm{mg} \mathrm{m}^{-3}$, occurred regularly every year between 1997 and 2010. This result is in line with other subantarctic islands, i.e., those of the Kerguelen or Crozet plateaus, where shelf-sediment interactions and local circulation provide a reliable annual supply of iron to the bloom region. The described regularity, size and intensity of South Georgia phytoplankton blooms will indeed lead to an atmospheric $\mathrm{CO}_{2}$ drawdown potentially greater than what previously estimated from smaller scale studies. Chl $a$ concentrations invariably peaked around December, and in many years peaked a second time between late January and April. Given the predominance of diatoms in the spring bloom and a most likely continuous advection of iron from the island, we attribute the second peak to a renewed supply of silicate which in January are reaching limiting concentrations and hence terminate the first (i.e., spring) bloom. To date only very few regional studies have reported bimodal bloom patterns in the open Southern Ocean, and more studies, including biogeochemical modelling, are needed to help investigate the environmental controls behind it.

The recurrence and regularity of blooms described here is in marked contrast with Park et al. (2010) who showed a time series of weak and unpredictable South Georgia phytoplank- ton blooms. We point out that these significant differences arise from differences in location and extent of the study areas chosen. In fact, because the local flow is strongly constrained by topography and hence the bloom boundaries vary little in time, averaging areas substantially different from the typical bloom area used here will necessarily exclude bloom waters or include others where blooms are rare or missing, hence introducing a systematic bias in the Chl $a$ concentration analysis.

Acknowledgements. The authors thank P. Assmy, O. Aumont, C. Klass, V. Strass, M. R. v. d. Loeff and C. Völker for valuable discussions. Particular thanks go to Victor Smetacek for sharing his insight into the ecology and dynamics of phytoplankton blooms in the Southern Ocean. M. P. Jouandet and the anonymous reviewer are also acknowledged, as their comments greatly improved the technical and scientific quality of the present manuscript. Financial support was provided by the Earth System Science Research School at the Alfred Wegener Institute for Polar and Marine Research and the EU FP7 project CARBOCHANGE under grant agreement no. 264879.

Edited by: K. Suzuki

\section{References}

Ardelan, M. V., Holm-Hansen, O., Hewes, C. D., Reiss, C. S., Silva, N. S., Dulaiova, H., Steinnes, E., and Sakshaug, E.: Natural iron enrichment around the Antarctic Peninsula in the Southern Ocean, Biogeosciences, 7, 11-25, doi:10.5194/bg-7-11-2010, 2010.

Arrigo, K. R., Robinson, D. H., Worthen, D. L., Dunbar, R. B., DiTullio, G. R., VanWoert, M., and Lizotte, M. P.: Phytoplankton Community Structure and the Drawdown of Nutrients and $\mathrm{CO}_{2}$ in the Southern Ocean, Science, 283, 365-367, doi:10.1126/science.283.5400.365, 1999.

Arrigo, K. R., van Dijken, G. L., and Bushinsky, S.: Primary production in the Southern Ocean, 1997-2006, J. Geophys. Res., 113, C08004, doi:10.1029/2007jc004551, 2008.

Atkinson, A., Whitehouse, M. J., Priddle, J., Cripps, G. C., Ward, P., and Brandon, M. A.: South Georgia, Antarctica: a productive, cold water, pelagic ecosystem, Mar. Ecol.-Prog. Ser., 216, 279308, doi:10.3354/meps216279, 2001.

Bakker, D. C. E., Nielsdóttir, M. C., Morris, P. J., Venables, H. J., and Watson, A. J.: The island mass effect and biological carbon uptake for the subantarctic Crozet Archipelago, Deep-Sea Res. Pt. II, 54, 2174-2190, doi:10.1016/j.dsr2.2007.06.009, 2007.

Blain, S., Sarthou, G., and Laan, P.: Distribution of dissolved iron during the natural iron-fertilization experiment KEOPS (Kerguelen Plateau, Southern Ocean), Deep-Sea Res. Pt. II, 55, 594-605, doi:10.1016/j.dsr2.2007.12.028, 2008.

Boehme, L., Meredith, M. P., Thorpe, S. E., Biuw, M., and Fedak, M.: Antarctic Circumpolar Current frontal system in the South Atlantic: Monitoring using merged Argo and animal-borne sensor data, J. Geophys. Res., 113, C09012, doi:10.1029/2007jc004647, 2008. 
Boutin, J. and Merlivat, L.: New in situ estimates of carbon biological production rates in the Southern Ocean from CARIOCA drifter measurements, Geophys. Res. Lett., 36, L13608, doi:10.1029/2009g1038307, 2009.

Boyd, P. W., Jickells, T., Law, C. S., Blain, S., Boyle, E. A., Buesseler, K. O., Coale, K. H., Cullen, J. J., de Baar, H. J. W., Follows, M., Harvey, M., Lancelot, C., Levasseur, M., Owens, N. P. J., Pollard, R., Rivkin, R. B., Sarmiento, J., Schoemann, V., Smetacek, V., Takeda, S., Tsuda, A., Turner, S., and Watson, A. J.: Mesoscale Iron Enrichment Experiments 19932005: Synthesis and Future Directions, Science, 315, 612-617, doi:10.1126/science.1131669, 2007.

Boyer, T. P., Antonov, J. I., Baranova, O. K., Garcia, H. E., Johnso, D. R., Locarnini, R. A., Mishonov, A. V., O’Brien, T. D., Seidov, D., Smolyar, I. V., and M. M. Zweng, DVDs.: World Ocean Database 2009, edited by: Levitus, S., NOAA Atlas NESDIS 66, US Gov. Printing Office, Washington, DC, 216 pp., DVDs, 2009.

Chever, F., Sarthou, G., Bucciarelli, E., Blain, S., and Bowie, A. R.: An iron budget during the natural iron fertilisation experiment KEOPS (Kerguelen Islands, Southern Ocean), Biogeosciences, 7, 455-468, doi:10.5194/bg-7-455-2010, 2010.

Comiso, J. C., McClain, C. R., Sullivan, C. W., Ryan, J. P., and Leonard, C. L.: Coastal Zone Color Scanner Pigment Concentrations in the Southern Ocean and Relationships to Geophysical Surface Features, J. Geophys. Res., 98, 2419-2451, doi:10.1029/92jc02505, 1993.

de Jong, J., Schoemann, V., Lannuzel, D., Croot, P., de Baar, H., and Tison, J.-L.: Natural iron fertilization of the Atlantic sector of the Southern Ocean by continental shelf sources of the Antarctic Peninsula, J. Geophys. Res., 117, G01029, doi:10.1029/2011jg001679, 2012.

Dong, S., Sprintall, J., Gille, S. T., and Talley, L.: Southern Ocean mixed-layer depth from Argo float profiles, J. Geophys. Res., 113, C06013, doi:10.1029/2006JC004051, 2008.

Dulaiova, H., Ardelan, M. V., Henderson, P. B., and Charette, M. A.: Shelf-derived iron inputs drive biological productivity in the southern Drake Passage, Global Biogeochem. Cy., 23, GB4014, doi:10.1029/2008gb003406, 2009.

Falkowski, P. G., Barber, R. T., and Smetacek, V.: Biogeochemical Controls and Feedbacks on Ocean Primary Production, Science, 281, 200-206, doi:10.1126/science.281.5374.200, 1998.

Fitch, D. T. and Moore, J. K.: Wind speed influence on phytoplankton bloom dynamics in the Southern Ocean Marginal Ice Zone, J. Geophys. Res., 112, C08006, doi:10.1029/2006jc004061, 2007.

Garcia, C. A. E., Garcia, V. M. T., and McClain, C. R.: Evaluation of SeaWiFS chlorophyll algorithms in the Southwestern Atlantic and Southern Oceans, Remote Sens. Environ., 95, 125137, doi:10.1016/j.rse.2004.12.006, 2005.

Gassó, S. and Stein, A. F.: Does dust from Patagonia reach the sub-Antarctic Atlantic Ocean?, Geophys. Res. Lett., 34, L01801, doi:10.1029/2006g1027693, 2007.

Gassó, S., Stein, A., Marino, F., Castellano, E., Udisti, R., and Ceratto, J.: A combined observational and modeling approach to study modern dust transport from the Patagonia desert to East Antarctica, Atmos. Chem. Phys., 10, 8287-8303, doi:10.5194/acp-10-8287-2010, 2010.

Hewes, C. D., Reiss, C. S., Kahru, M., Mitchell, B. G., and HolmHansen, O.: Control of phytoplankton biomass by dilution and mixed layer depth in the western Weddell-Scotia Confluence,
Mar. Ecol.-Prog. Ser., 366, 15-19, doi:10.3354/meps07515, 2008.

Hinz, D. J., Nielsdóttir, M. C., Korb, R. E., Whitehouse, M. J., Poulton, A. J., Moore, C. M., Achterberg, E. P., and Bibby, T. S.: Responses of microplankton community structure to iron addition in the Scotia Sea, Deep-Sea Res. Pt. II, 59-60, 36-46, doi:10.1016/j.dsr2.2011.08.006, 2012.

Hogg, O. T., Barnes, D. K. A., and Griffiths, H. J.: Highly Diverse, Poorly Studied and Uniquely Threatened by Climate Change: An Assessment of Marine Biodiversity on South Georgia's Continental Shelf, PLoS ONE, 6, e19795, doi:10.1371/journal.pone.0019795, 2011.

Holeton, C., Nédélec, F., Sanders, R., Brown, L., Moore, C., Stevens, D., Heywood, K., Statham, P., and Lucas, C.: Physiological state of phytoplankton communities in the Southwest Atlantic sector of the Southern Ocean, as measured by fast repetition rate fluorometry, Polar Biol., 29, 44-52, doi:10.1007/s00300-005-0028-y, 2005.

Holm-Hansen, O., Kahru, M., Hewes, C. D., Kawaguchi, S., Kameda, T., Sushin, V. A., Krasovski, I., Priddle, J., Korb, R., Hewitt, R. P., and Mitchell, B. G.: Temporal and spatial distribution of chlorophyll- $a$ in surface waters of the Scotia Sea as determined by both shipboard measurements and satellite data, DeepSea Res. Pt. II, 51, 1323-1331, doi:10.1016/j.dsr2.2004.06.004, 2004.

Hopkinson, B. M., Mitchell, B. G., Reynolds, R. A., Wang, H., Selph, K. E., Measures, C. I., Hewes, C. D., Holm-Hansen, O., and Barbeau, K. A.: Iron Limitation across Chlorophyll Gradients in the Southern Drake Passage: Phytoplankton Responses to Iron Addition and Photosynthetic Indicators of Iron Stress, Limnol. Oceanogr., 52, 2540-2554, 2007.

Jones, E. M., Bakker, D. C. E., Venables, H. J., and Watson, A. J.: Dynamic seasonal cycling of inorganic carbon downstream of South Georgia, Southern Ocean, Deep-Sea Res. Pt II, 59-60, 25-35, doi:10.1016/j.dsr2.2011.08.001, 2012.

Jouandet, M. P., Blain, S., Metzl, N., Brunet, C., Trull, T. W., and Obernosterer, I.: A seasonal carbon budget for a naturally iron-fertilized bloom over the Kerguelen Plateau in the Southern Ocean, Deep-Sea Res. Pt. II, 55, 856-867, doi:10.1016/j.dsr2.2007.12.037, 2008.

Jouandet, M. P., Blain, S., Metzl, N., and Mongin, M.: Interannual variability of net community production and air-sea $\mathrm{CO}_{2}$ flux in a naturally iron fertilized region of the Southern Ocean (Kerguelen Plateau), Antarct. Sci., 23, 589-596, doi:10.1017/S0954102011000411, 2011.

Kahru, M., Mitchell, B. G., Gille, S. T., Hewes, C. D., and Holm-Hansen, O.: Eddies enhance biological production in the Weddell-Scotia Confluence of the Southern Ocean, Geophys. Res. Lett., 34, L14603, doi:10.1029/2007g1030430, 2007.

Korb, R. E. and Whitehouse, M.: Contrasting primary production regimes around South Georgia, Southern Ocean: large blooms versus high nutrient, low chlorophyll waters, Deep-Sea Res. Pt. I, 51, 721-738, doi:10.1016/j.dsr.2004.02.006, 2004.

Korb, R. E., Whitehouse, M. J., and Ward, P.: SeaWiFS in the southern ocean: spatial and temporal variability in phytoplankton biomass around South Georgia, Deep-Sea Res. Pt. II, 51, 99-116, doi:10.1016/j.dsr2.2003.04.002, 2004.

Korb, R. E., Whitehouse, M. J., Atkinson, A., and Thorpe, S. E.: Magnitude and maintenance of the phytoplankton bloom at 
South Georgia: a naturally iron-replete environment, Mar. Ecol.Prog. Ser., 368, 75-91, doi:10.3354/meps07525, 2008.

Korb, R. E., Whitehouse, M. J., Gordon, M., Ward, P., and Poulton, A. J.: Summer microplankton community structure across the Scotia Sea: implications for biological carbon export, Biogeosciences, 7, 343-356, doi:10.5194/bg-7-343-2010, 2010.

Korb, R. E., Whitehouse, M. J., Ward, P., Gordon, M., Venables, H. J., and Poulton, A. J.: Regional and seasonal differences in microplankton biomass, productivity, and structure across the Scotia Sea: Implications for the export of biogenic carbon, Deep-Sea Res. Pt. II, 59-60, 67-77, doi:10.1016/j.dsr2.2011.06.006, 2012.

Lannuzel, D., Schoemann, V., de Jong, J., Tison, J.-L., and Chou, L.: Distribution and biogeochemical behaviour of iron in the East Antarctic sea ice, Mar. Chem., 106, 18-32, doi:10.1016/j.marchem.2006.06.010, 2007.

Lin, H., Rauschenberg, S., Hexel, C. R., Shaw, T. J., and Twining, B. S.: Free-drifting icebergs as sources of iron to the Weddell Sea, Deep-Sea Res. Pt. II, 58, 1392-1406, doi:10.1016/j.dsr2.2010.11.020, 2011.

Lourantou, A. and Metzl, N.: Decadal evolution of carbon sink within a strong bloom area in the subantarctic zone, Geophys. Res. Lett., 38, L23608, doi:10.1029/2011g1049614, 2011.

Lutz, V. A., Segura, V., Dogliotti, A. I., Gagliardini, D. A., Bianchi, A. A., and Balestrini, C. F.: Primary production in the Argentine Sea during spring estimated by field and satellite models, J. Plankton Res., 32, 181-195, doi:10.1093/plankt/fbp117, 2010.

Martin, J. H., Fitzwater, S. E., and Gordon, R. M.: Iron deficiency limits phytoplankton growth in antarctic waters, Global Biogeochem. Cy., 4, 5-12, doi:10.1029/GB004i001p00005, 1990.

Martinez, E., Antoine, D., D’Ortenzio, F., and de Boyer Montégut, C.: Phytoplankton spring and fall blooms in the North Atlantic in the 1980s and 2000s, J. Geophys. Res., 116, C11029, doi:10.1029/2010jc006836, 2011.

McClain, C. R., Cleave, M. L., Feldman, G. C., Gregg, W. W., Hooker, S. B., and Kuring, N.: Science quality SeaWiFS data for global biosphere research, Sea Technol., 39, 10-16, 1998.

Meredith, M. P., Watkins, J. L., Murphy, E. J., Cunningham, N. J., Wood, A. G., Korb, R., Whitehouse, M. J., Thorpe, S. E., and Vivier, F.: An anticyclonic circulation above the Northwest Georgia Rise, Southern Ocean, Geophys. Res. Lett., 30, 2061, doi:10.1029/2003g1018039, 2003.

Mongin, M., Molina, E., and Trull, T. W.: Seasonality and scale of the Kerguelen plateau phytoplankton bloom: A remote sensing and modeling analysis of the influence of natural iron fertilization in the Southern Ocean, Deep-Sea Res. Pt. II, 55, 880-892, doi:10.1016/j.dsr2.2007.12.039, 2008.

Monterey, G. and Levitus, S.: Seasonal Variability of Mixed Layer Depth for the World Ocean, NOAA Atlas NESDIS 14, US Gov. Printing Office, Washington, DC, 1997.

Moore, J. K. and Abbott, M. R.: Phytoplankton chlorophyll distributions and primary production in the Southern Ocean, J. Geophys. Res., 105, 28709-28722, doi:10.1029/1999jc000043, 2000.

Moore, J. K., Abbott, M. R., and Richman, J. G.: Location and dynamics of the Antarctic Polar Front from satellite sea surface temperature data, J. Geophys. Res., 104, 3059-3073, doi:10.1029/1998jc900032, 1999.

Nielsdóttir, M. C., Bibby, T. S., Moore, C. M., Hinz, D. J., Sanders, R., Whitehouse, M., Korb, R., and Achterberg, E. P.: Seasonal and spatial dynamics of iron availability in the Scotia Sea, Mar.
Chem., 130-131, 62-72, doi:10.1016/j.marchem.2011.12.004, 2012.

Nishioka, J., Ono, T., Saito, H., Sakaoka, K., and Yoshimura, T.: Oceanic iron supply mechanisms which support the spring diatom bloom in the Oyashio region, western subarctic Pacific, J. Geophys. Res., 116, C02021, doi:10.1029/2010jc006321, 2011.

Orsi, A. H., Whitworth, T., and Nowlin, W. D.: On the meridional extent and fronts of the Antarctic Circumpolar Current, DeepSea Res. Pt. I, 42, 641-673, doi:10.1016/0967-0637(95)00021W, 1995.

Park, J., Oh, I.-S., Kim, H.-C., and Yoo, S.: Variability of SeaWiFS chlorophyll-a in the southwest Atlantic sector of the Southern Ocean: Strong topographic effects and weak seasonality, DeepSea Res. Pt. I, 57, 604-620, doi:10.1016/j.dsr.2010.01.004, 2010.

Planquette, H., Statham, P. J., Fones, G. R., Charette, M. A., Moore, C. M., Salter, I., Nédélec, F. H., Taylor, S. L., French, M., Baker, A. R., Mahowald, N., and Jickells, T. D.: Dissolved iron in the vicinity of the Crozet Islands, Southern Ocean, Deep-Sea Res. Pt. II, 54, 1999-2019, doi:10.1016/j.dsr2.2007.06.019, 2007.

Pollard, R. T., Salter, I., Sanders, R. J., Lucas, M. I., Moore, C. M., Mills, R. A., Statham, P. J., Allen, J. T., Baker, A. R., Bakker, D. C. E., Charette, M. A., Fielding, S., Fones, G. R., French, M., Hickman, A. E., Holland, R. J., Hughes, J. A., Jickells, T. D., Lampitt, R. S., Morris, P. J., Nedelec, F. H., Nielsdottir, M., Planquette, H., Popova, E. E., Poulton, A. J., Read, J. F., Seeyave, S., Smith, T., Stinchcombe, M., Taylor, S., Thomalla, S., Venables, H. J., Williamson, R., and Zubkov, M. V.: Southern Ocean deep-water carbon export enhanced by natural iron fertilization, Nature, 457, 577-580, doi:10.1038/nature07716, 2009.

Poulton, A. J., Mark Moore, C., Seeyave, S., Lucas, M. I., Fielding, S., and Ward, P.: Phytoplankton community composition around the Crozet Plateau, with emphasis on diatoms and Phaeocystis, Deep-Sea Res. Pt. II, 54, 2085-2105, doi:10.1016/j.dsr2.2007.06.005, 2007.

Schlitzer, R.: Ocean Data View, http://odv.awi.de, 2012.

Smetacek, V. and Naqvi, S. W. A.: The next generation of iron fertilization experiments in the Southern Ocean, Philos. T. R. Soc. A., 366, 3947-3967, doi:10.1098/rsta.2008.0144, 2008.

Smetacek, V., Assmy, P., and Henjes, J.: The role of grazing in structuring Southern Ocean pelagic ecosystems and biogeochemical cycles, Antarct. Sci., 16, 541-558, doi:10.1017/S0954102004002317, 2004.

Smith, R. C., Martinson, D. G., Stammerjohn, S. E., Iannuzzi, R. A., and Ireson, K.: Bellingshausen and western Antarctic Peninsula region: Pigment biomass and sea-ice spatial/temporal distributions and interannual variabilty, Deep-Sea Res. Pt. II, 55, 1949-1963, doi:10.1016/j.dsr2.2008.04.027, 2008.

Szeto, M., Werdell, P. J., Moore, T. S., and Campbell, J. W.: Are the world's oceans optically different?, J. Geophys. Res., 116, C00H04, doi:10.1029/2011jc007230, 2011.

Thomalla, S. J., Fauchereau, N., Swart, S., and Monteiro, P. M. S.: Regional scale characteristics of the seasonal cycle of chlorophyll in the Southern Ocean, Biogeosciences, 8, 2849-2866, doi:10.5194/bg-8-2849-2011, 2011.

Thorpe, S. E., Heywood, K. J., Brandon, M. A., and Stevens, D. P.: Variability of the southern Antarctic Circumpolar Current front north of South Georgia, J. Mar. Syst., 37, 87-105, doi:10.1016/S0924-7963(02)00197-5, 2002. 
Trull, T. W., Bray, S. G., Manganini, S. J., Honjo, S., and François, R.: Moored sediment trap measurements of carbon export in the Subantarctic and Polar Frontal Zones of the Southern Ocean, south of Australia, J. Geophys. Res., 106, 31489-31509, doi:10.1029/2000jc000308, 2001.

Venables, H. and Moore, C. M.: Phytoplankton and light limitation in the Southern Ocean: Learning from high-nutrient, high-chlorophyll areas, J. Geophys. Res., 115, C02015, doi:10.1029/2009jc005361, 2010.

Venables, H., Meredith, M. P., Atkinson, A., and Ward, P.: Fronts and habitat zones in the Scotia Sea, Deep-Sea Res. Pt. II, 59-60, 14-24, doi:10.1016/j.dsr2.2011.08.012, 2012.

Ward, P., Shreeve, R., Whitehouse, M., Korb, B., Atkinson, A., Meredith, M., Pond, D., Watkins, J., Goss, C., and Cunningham, N.: Phyto- and zooplankton community structure and production around South Georgia (Southern Ocean) during Summer 2001/02, Deep-Sea Res. Pt. I, 52, 421-441, doi:10.1016/j.dsr.2004.10.003, 2005.

Whitehouse, M. J., Korb, R. E., Atkinson, A., Thorpe, S. E., and Gordon, M.: Formation, transport and decay of an intense phytoplankton bloom within the High-Nutrient LowChlorophyll belt of the Southern Ocean, J. Mar. Syst., 70, 150167, doi:10.1016/j.jmarsys.2007.05.003, 2008a.
Whitehouse, M. J., Meredith, M. P., Rothery, P., Atkinson, A., Ward, P., and Korb, R. E.: Rapid warming of the ocean around South Georgia, Southern Ocean, during the 20th century: Forcings, characteristics and implications for lower trophic levels, DeepSea Res. Pt. I, 55, 1218-1228, doi:10.1016/j.dsr.2008.06.002, $2008 b$.

Whitehouse, M. J., Atkinson, A., Ward, P., Korb, R. E., Rothery, P., and Fielding, S.: Role of krill versus bottom-up factors in controlling phytoplankton biomass in the northern Antarctic waters of South Georgia, Mar. Ecol.-Prog. Ser., 393, 69-82, doi:10.3354/meps08288, 2009.

Whitehouse, M. J., Atkinson, A., Korb, R. E., Venables, H. J., Pond, D. W., and Gordon, M.: Substantial primary production in the land-remote region of the central and northern Scotia Sea, DeepSea Res. Pt. II, 59-60, 47-56, doi:10.1016/j.dsr2.2011.05.010, 2012.

Young, E. F., Meredith, M. P., Murphy, E. J., and Carvalho, G. R.: High-resolution modelling of the shelf and open ocean adjacent to South Georgia, Southern Ocean, Deep-Sea Res. Pt. II, 58, 1540-1552, doi:10.1016/j.dsr2.2009.11.003, 2011. 